\title{
Striped Hyaena Hyaena hyaena (Linnaeus, 1758) (Carnivora: Hyaenidae) new reports in Nandhaur Valley, Terai Arc Landscape, Uttarakhand, India
}

\author{
Shah Mohammad Belal ${ }^{1}$, Nasim Ahmad Ansari ${ }^{*}$ \\ ${ }^{1}$ Department of Forestry and Environmental Science, Kumaun University, Nainital, Uttarakhand, India \\ ${ }^{2}$ Wildlife Institute of India, Chandrabani, Dehradun, Uttarakhand, India
}

\begin{abstract}
Striped Hyaena Hyaena hyaena Linnaeus, 1758 species is one of the largest carnivores found in Indian Subcontinent reported for first time in the Nandhaur Valley in Terai Arc Landscape, Uttarakhand, India. Diagnosis and photograph of the species is provided.
\end{abstract}

Keywords - Striped Hyaena, Nandhaur Valley, Terai Arc Landscape, India, New record.

\section{INTRODUCTION}

The Terai Arc Landscape (TAL) of Uttarakhand, India has most well-known wildlife such as tigers, elephants and rhinos along with a large variety of other rare, endangered and endemic wildlife species. Nandhaur Valley is a favorable site to attempt a revival of large mammal populations (Johnsingh and Pandav 2008). The Nandhaur river valley, lying at the core of this landscape, receives mention in several accounts for its plentiful game and fish (Corbett 1944; Corbett 1954). The Striped Hyaena Hyaena hyaena Linnaeus, 1758 is one of the largest carnivores in India (Sharma et al 2011) and found in Africa, Middle East and Indian sub-continents (Ahmad et al 2012) especially in semi-arid landscape (Sharma et al 2011; Singh et al 2010; Alam and Khan 2015) of India and prefers rocky and open landscapes (Mills and Hofer 1998). The Striped Hyaena is regarded rare and kept under schedule I of the Indian Wildlife (Protection) Act-1972 and documented as a nearthreatened species by International Union for the Conservation of Nature (IUCN), due to the habitat destruction their compromised population size shrinking throughout their distribution range (Arumugam et al 2008) and need of complete protection for long term survival. In the present study, we report the Striped Hyaena Hyaena hyaena for the first time in Nandhaur Valley in Terai Arc Landscape, Uttarakhand, India.

\section{MATERIALS AND METHODS}

The study was conducted to count the tiger and its associated species in the three territorial forest divisions-
Haldwani, Terai East and Champawat, in Terai Arc Landscape (Figure 1), Uttarakhand, India through camera trap method from October 2011 to April 2012. Diagnosis and a photograph of the species have been provided. The photographic specimen submitted to Uttarakhand Forest Department and WWF-India Secretariat for record.

\section{RESULTS AND DISCUSSION}

The Striped Hyaena Hyaena hyaena was recorded during the study of tiger and its associated species through camera trapping from October 2011 to April 2012 in Nandhaur Valley including three territorial forest divisions, Haldwani, Terai East and Champawat, in Terai Arc Landscape, Uttarakhand, India. Striped Hyaena Hyaena hyaena was captured on 19 December 2011 at 4.22 AM in one camera (Figure 2) and on 19 December 2011 at $4.36 \mathrm{AM}$ in another camera (Figure 3). The sightings were located on $29^{\circ}$ $06^{\prime} 18.5^{\prime \prime} \mathrm{N} 79^{\circ} 43^{\prime} 31.2^{\prime \prime} \mathrm{E}$ (Figure 4) in the HaldwaniTanakpur forest road (Figure 5). The sightings were also confirmed individually by peoples from neighboring villages by showing photographs. As reported by local people, this species was previously never been sighted in the entire range of Uttarakhand and also never been recorded earlier in this landscape. The species was captured is a rocky and edge of mixed habitat near the river at an altitude of $276 \mathrm{msl}$. The mixed habitat was dominated by Shorea robusta, Acacia catechu, Holoptelea integrifolia, Holarrhena antidysenterica, Aegle marmelos, Mallotus philippensis and Grewia oppositifolia and the bushes are Lantana camara and Murraya koenigii.

\section{CONCLUSION}

The Striped Hyaena Hyaena hyaena has been considered as a typical scavenger, existing around human settlements and feeding of carcasses of animals and also sometimes feeds on fruits, insects and reptiles (Mills and Hofer 1998, Kruk 1976). The detail study of status and ecology of Striped 
Hyaena in entire Uttarakhand is needed in urgent for the conservation of the species in this landscape.

\section{ACKNOWLEDGEMENTS}

The study was supported by WWF-India Secretariat under Tiger Census Project with the permission of Uttarakhand Forest Department, Government of India.

\section{REFERENCES}

[1] Ahmed FAM, Takona NY, Yousif RA, et al. 2012. Some Behavioral traits of Striped Hyaena under Captive Conditions. Journal of Life Science and Biomedicine 2(5):196-199.

[2] Alam S, Khan JA. 2015. Food habits of striped hyena (Hyaena hyaena) in a semi-arid conservation area of India. Journal of Arid Land 7(6):860-866.

[3] Arumugam R, Wagner A, Mills G. 2008. Hyaena hyaena. In: IUCN 2014. IUCN Red list of threatened species. Version 2014.3. [Internet] Available from: http://www.iucnredlist.org. [Date accessed: 19 January 2015.].

[4] Corbett J. 1944. Man-eaters of Kumaun. London: Oxford University Press.

[5] Corbett J. 1954. The temple tiger and more man-eaters of Kumaon. London: Oxford University Press.

[6] Fox MW. 1971. Ontogeny of a social display in Hyaena hyaena: anal protrusion. Journal of Mammalogy 52:467-469.

[7] Holzapfel M. 1939. Markierungsverhalten bei der Hyäne. Zeitschrift für Morphologie und Ökologie der Tiere 35:10-13.
[8] Johnsingh AJT, Pandav B. 2008. Chowgarh to Chorgalia- walking in Corbett country. Sanctuary Asia 28-35.

[9] Kruk H. 1976. Feeding and social behavior of the striped hyaena (Hyaena hyaena). East African wildlife journal 14:91-111.

[10] Mills G, Hofer H. 1998. Status survey and conservation action plan hyenas. Oxford: UK IUCN/SSC, Information Press.

[11] Pocock RI. 1934. The races of the striped and brown hyaenas. Proceedings of the Zoological Society of London 799-825.

[12] Rieger I. 1978. Social behaviour of the striped hyaena at Zürich Zoo. Carnivore 1(2):49-60.

[13] Schneider KM. 1926. Über Hyänenzucht, Teil I. Die Pelztierzucht 2(8):1-4.

[14] Schneider KM. 1926. Über Hyänenzucht, Teil II. Die Pelztierzucht 2(9):9-11.

[15] Schneider KM. 1926. Über Hyänenzucht, Teil III. Die Pelztierzucht 2(10):12-14.

[16] Sharma G, Vijay P, Rajpurohit LS, Ram C. 2011. Ecobehaviour study and status of Striped Hyaena (Hyaena Hyaena Linnaeus, 1758) in South Western Rajasthan, India. Journal of Evolutionary Biology Research 3(4):44-46.

[17] Singh P, Gopalaswamy AM, Karanth KU. 2010. Factors influencing densities of striped hyenas (Hyaena hyaena) in arid regions of India. Journal of Mammalogy 91(5):1152-1159.

[18] Wagner AP. Frank LG, Creel S, Coscia EM. 2007. Transient genital anomalies in the striped hyena. Hormones and Behavior 51:626-632. 


\section{FIGURES}

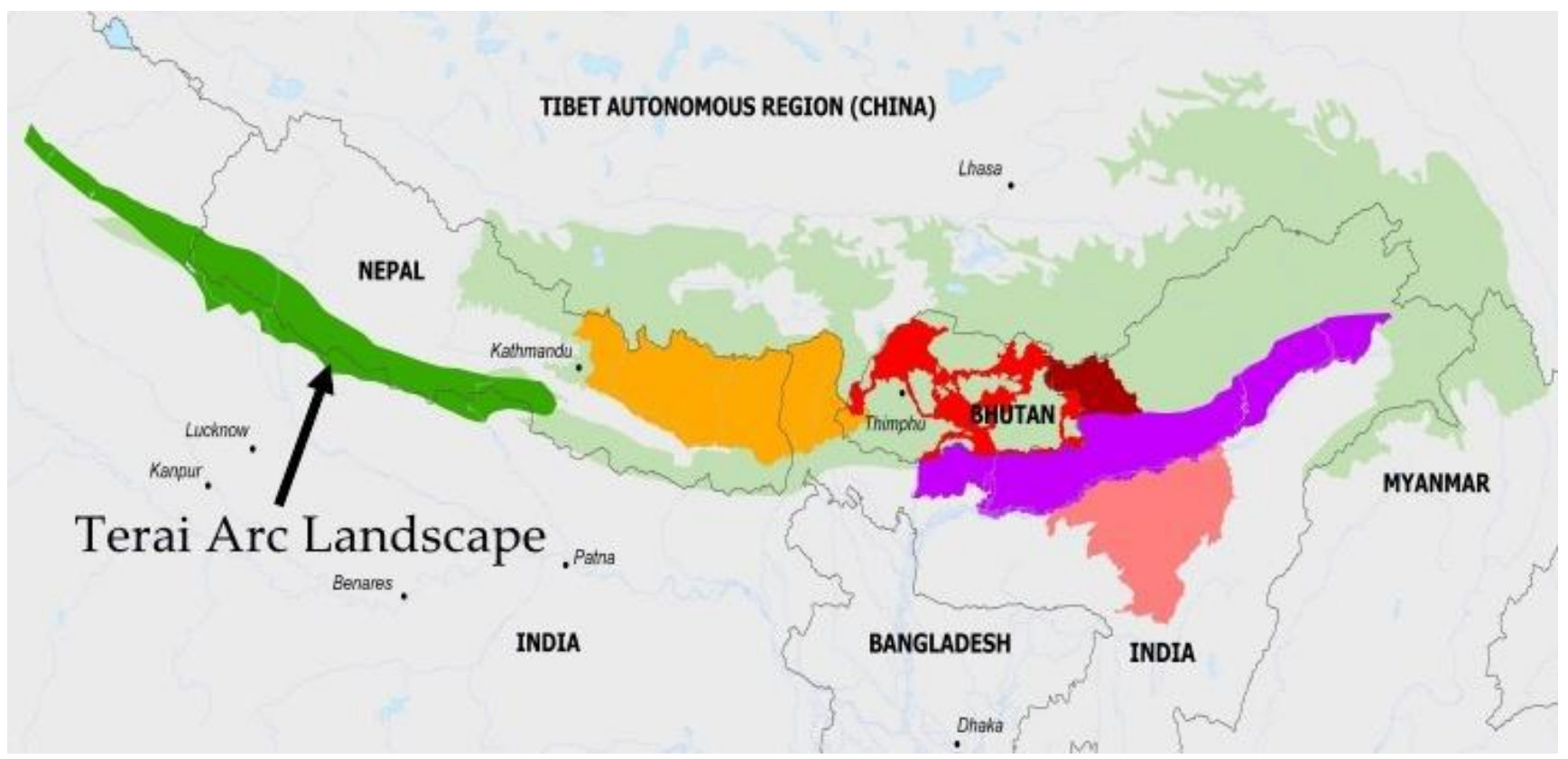

Fig.1: Map showing Terai Arc Landscape, India

(Source: WWF-India)

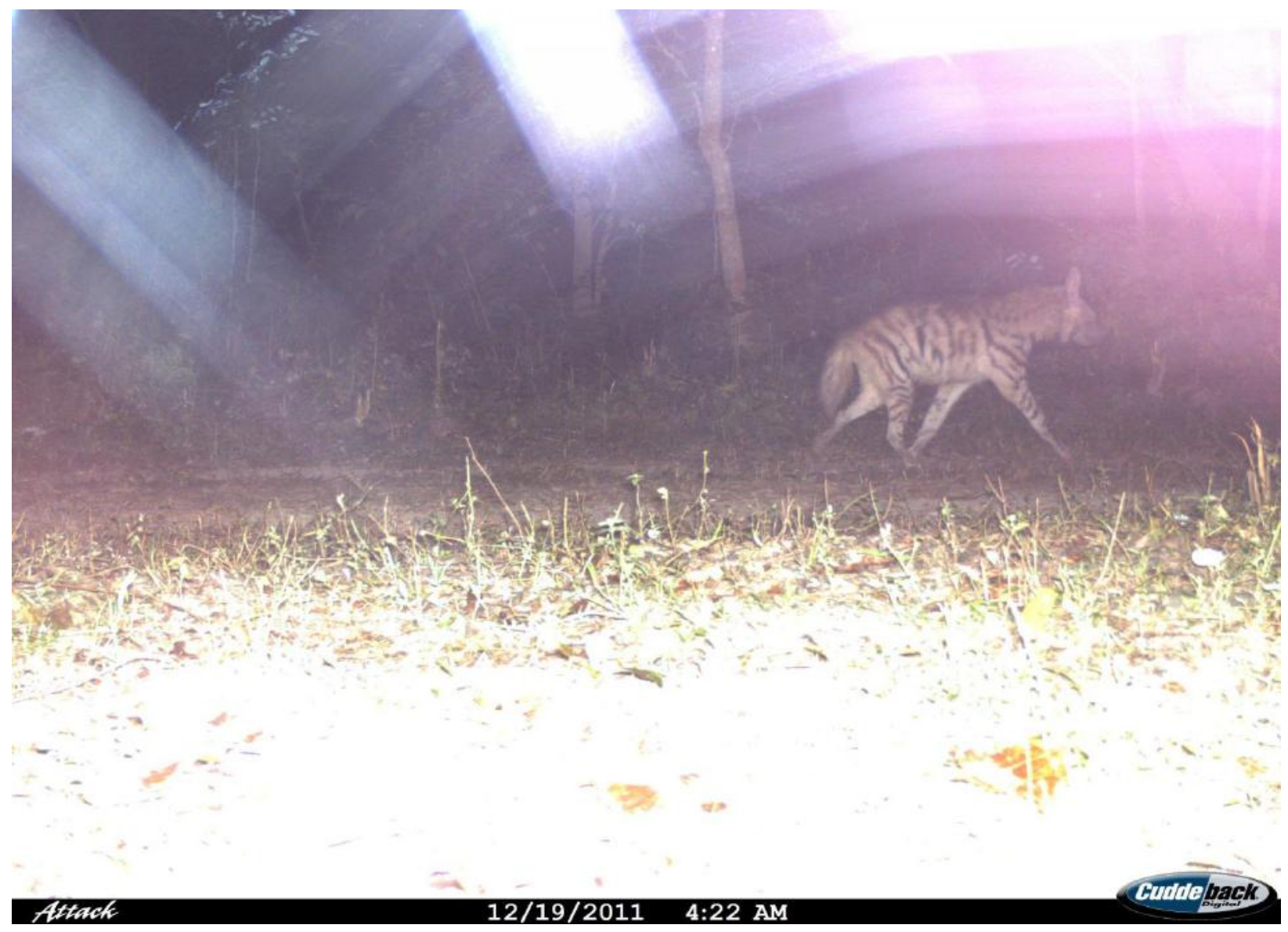

Fig.2: Striped Hyaena photo in Camera Trap at 4:22 AM 

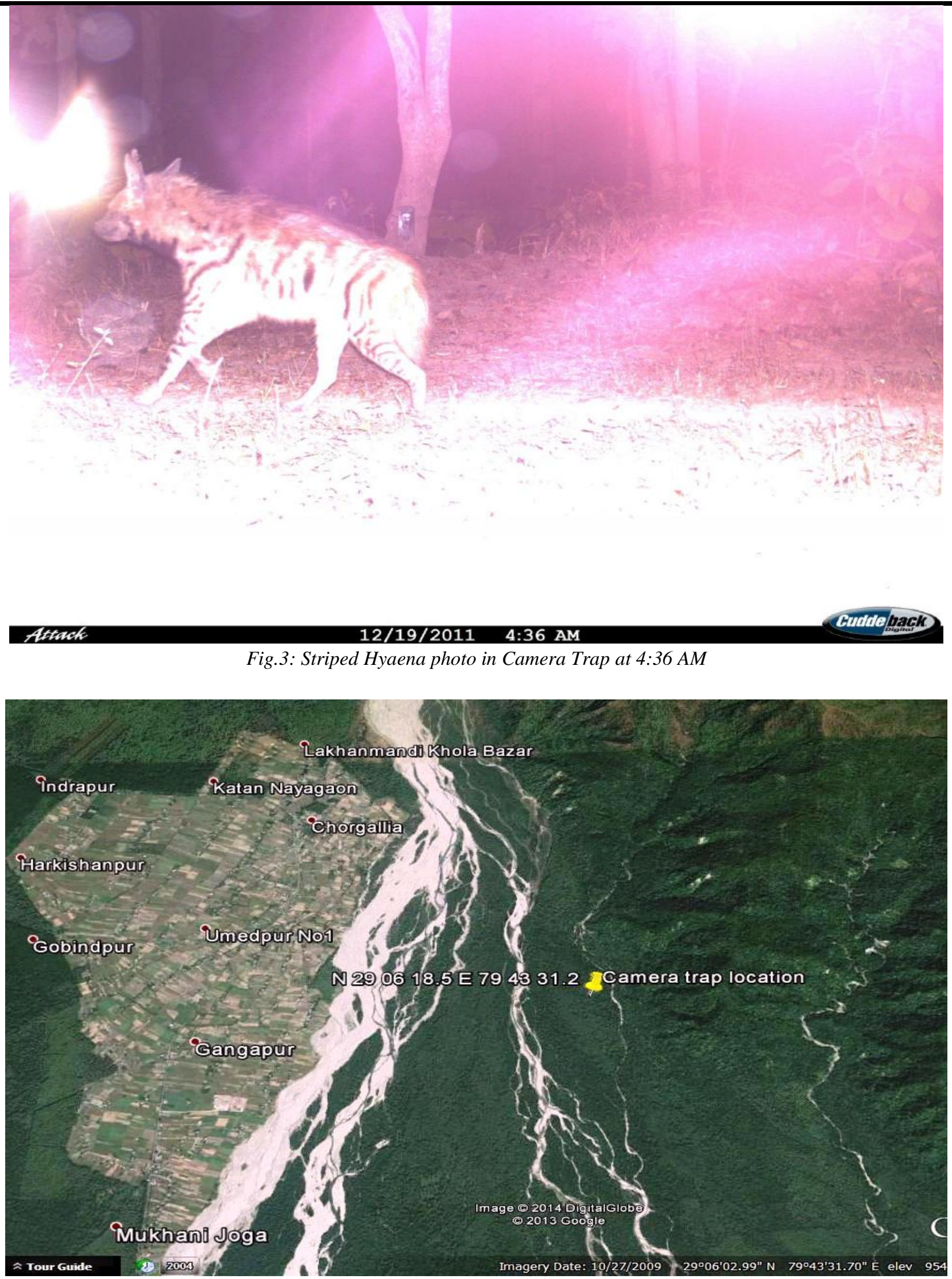

Fig.4: Camera traps location of Striped Hyaena in the study area. 


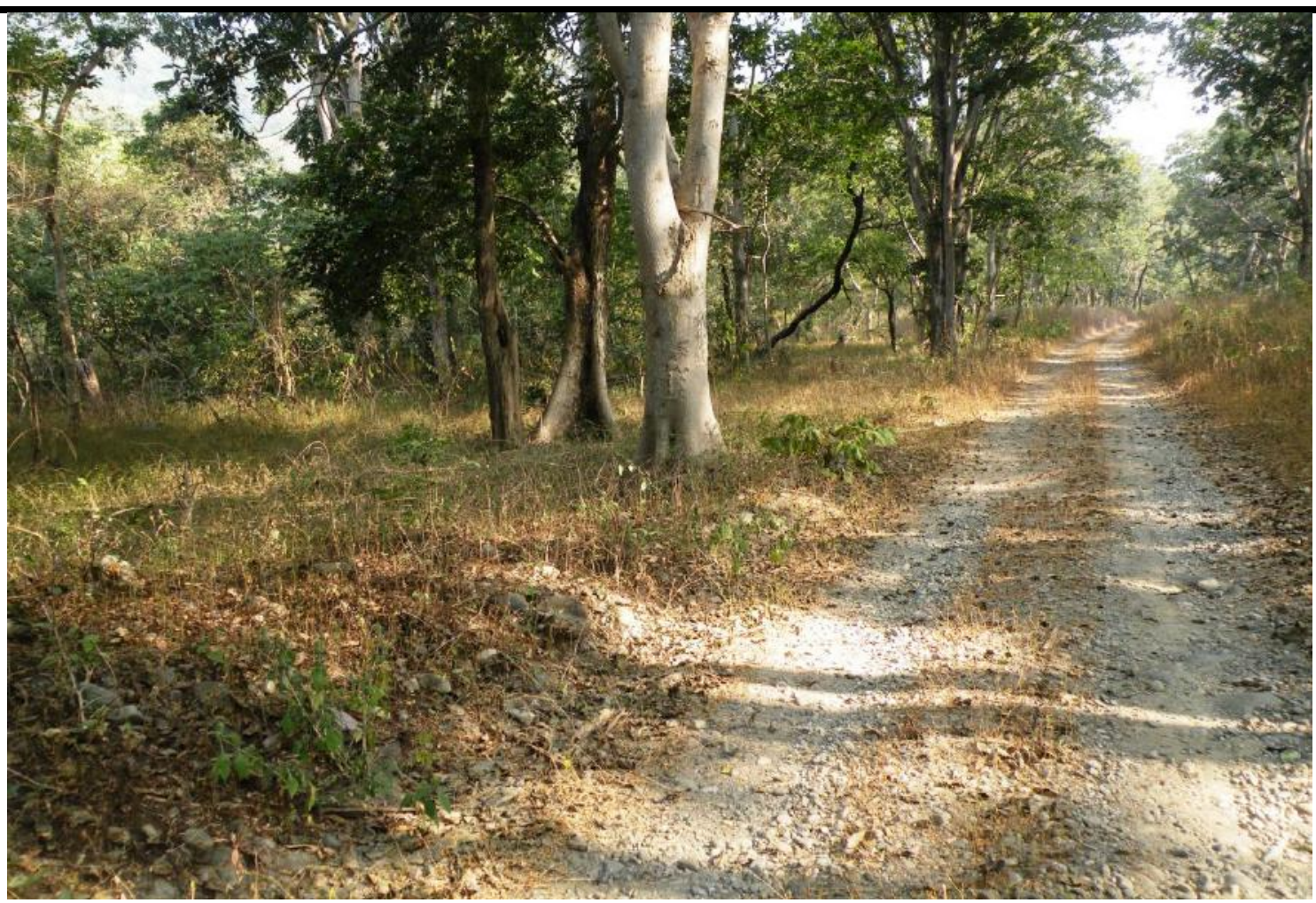

Fig.5: Striped Hyaena habitat in the study area. 